\title{
Service Oriented Architecture (SOA) and Fuzzy AHP-SAW for Lecturer Performance Analysis in Real-time
}

\author{
Moh. Ali Fikri ${ }^{1 *}$, Rahmat Gernowo ${ }^{2}$, Bayu Surarso $^{3}$ \\ ${ }^{1}$ Master of Information System, Post Graduated School, Diponegoro University, Semarang, Indonesia \\ ${ }^{2}$ Department of Physics, Faculty of Science and Mathematics, Diponegoro University, Semarang, \\ Indonesia \\ ${ }^{3}$ Department of Mathematics, Faculty of Science and Mathematics, Diponegoro University, \\ Semarang, Indonesia
}

\begin{abstract}
Service-Oriented Architecture (SOA) is a way to use web services to model large software systems. SOA architecture is also a successful model at the moment. SOA does not have a formula for analyzing data, so collaborative methods are needed that can present information that has added value. One of them is the Fuzzy AHP-SAW method to analyze the performance of lecturers at tertiary institutions with data sources applying SOA methods for data integration in academic information systems in real-time. Lecturer performance can be monitored in real time, so that it can be used as material for decision making at the Indramayu State Polytechnic appropriately. Message delivery services performed by the web service with 150 performance table records, 69 lecturer records tables, 6 record study programs and 3 record majors have been successful. fuzzy AHP fuzzy analysis method to find the best lecturers has been successfully carried out by producing fuzzy vector weights $(w)$ performance performance criteria (C1) 0.43, research (C2) 0.29, dedication (C3) 0.11 and publication (C4) 0.17 with the number of lecturers (alternative) as many as 69 . The results show an alternative code $\mathrm{A} 063$ with a $\mathrm{C} 1$ value of $0.38 \mathrm{C} 20.22 \mathrm{C} 30.08 \mathrm{C} 4$ 0.15 and a preference of 0.844 getting the first rank.
\end{abstract}

Keywords: Fuzzy AHP, SAW, SOA, Web Service, Lecturer

\section{Introduction}

Service-Oriented Architecture (SOA) is a way to use web services to model large software systems, where sub-software or computing components are distributed on different remote servers that provide services to other clients [1]. SOA architecture is a successful model at the moment. This architecture focuses its attention on business services provided by a system [2]. SOA architecture can be applied according to needs, that is, depending on how the service

* Corresponding author: mohammad.ali.fikri@gmail.com 
is implemented and provided to the client. SOA runs on the world wide web protocol using URLs to run remote data communication processes. Presentation of information transferred and received is using XML or JSON [2]. SOA can be applied to academic information systems at the college level with the aim of speeding up business processes on information systems available in an organization.

SOA does not have a formula for analyzing data, so collaborative methods are needed that can present information that has added value. One of them is the Fuzzy Analytic Hierarchy Process (FAHP) method to analyze the performance of lecturers at tertiary institutions with data sources applying SOA methods for data integration in academic information systems in real-time.

AHP (Analytic Hierarchy Process) developed by T. L. Saaty in the 70s of the 20th century is one of the methodologies applied [3-4]. Analytical Hierarchical Process (AHP) together with fuzzy set theory has been used extensively in Multi-Criteria Decision Making (MCDM) where fuzzy numbers are used to represent human valuations more realistically. Over the past few years, many articles have been published which propose algorithms through which priority vectors (or weight vectors) can be calculated from a fuzzy comparison matrix [3]. Fuzzy AHP (FAHP) is a development version of the Analytical Hierarchical Process (AHP) Saaty which has been widely discussed by the author and until now [6-10].

The Fuzzy AHP algorithm (FAHP) uses fuzzy numbers to represent the same preferences and they are recorded in fuzzy comparisons that match the trices. The main purpose of using fuzzy set theory into AHP is based on the argument that human judgment and preferences cannot analyze mathematical data accurately and precisely. This causes humans to make wrong decisions. Therefore we need computational assistance in solving data analysis problems using the Fuzzy AHP algorithm in helping humans to retrieve material [4].

Fuzzy Analytic Hierarchy Process (FAHP) has been carried out to analyze the teaching conception model and lecturer learning using a questionnaire with 85 student respondents [5]. Analysis of lecturer performance has also been carried out at the Textile Study Program of the Turkish Marmara University. The method and teaching attitude of the lecturer are evaluated [6]. Fuzzy AHP is a better choice for prioritizing weights from various types of data [7]. With Fuzzy ability, AHP does the weighting well so it needs the performance value needed, the best lecturer ranking can be done.

Simple Additive Weighting which is also known as a measurable linear combination or valuation method [8]. Finding the sum of the measured performance appraisals of each alternative on all alternative criteria with the highest overall score is the best alternative to be taken [9]. Simple Additive Weighting (SAW) has been successfully used to select the selection of new employees in Serbia [8]. The selection of flood-prone areas in Semarang using SAW has been successful [10]. AHP and SAW methods have also been implemented and proven to be successful in providing solutions to the problem of decision support systems for savings and loan cooperatives in Timor Leste [11]. Based on the relationship of relative preferences to solve decision problems easily and efficiently the SAW method is very easy to use [12].

Based on SOA and FAHP-SAW models that have been used by several researchers in the world can be applied in overcoming the problem of education in Indonesia. Education is a very important human need. Transforming learning in education for sustainability requires faculty and academic commitment. Through good education management, motivations and innovative ideas, changes in content and methods can be realized. Examples of overall curriculum reform and reorientation towards sustainability are relatively limited [13]. The internal quality assurance system of higher education is the plan, implementation, control, development of university quality standards consistently and continuously to get stakeholder satisfaction and ensure the quality of graduates in accordance with assigned competencies [14]. 
The role of lecturers in transforming knowledge to students becomes important and triggers the attention of researchers in the world [15]. Lecturers are professional educators and scientists with the main task of transforming, developing and disseminating science, technology. and art through education, research and community service. Based on the Republic of Indonesia government regulation number 37 of 2009 that the main task of the lecturer is to carry out the three tridharma of the university by conducting education, research and community service.

Thereby, the lecturer tridharma must be carried out properly in accordance with applicable regulations. But the number of lecturers in universities is increasing and will continue to grow so to be able to monitor the performance of lecturers will be difficult for management. For this reason, an information system is needed for analysis related to the performance of lecturers so that they are able to monitor and analyze performance properly and appropriately. This can also trigger career acceleration for the lecturer concerned.

Therefore in this study the performance analysis of lecturers uses tridharma data namely education (lecturer performance questionnaire), research, community service and publications. Most of the data has been stored in the academic information system database. Therefore Service Orient ed Architecture (SOA) and Fuzzy AHP-SAW methods for analyzing lecturer performance in real-time at the Indramayu State Polytechnic (POLINDRA) are very suitable and needed to improve the quality of lecturers, so they can be used as material for taking managerial decision to obtain a strategic work plan and be able to improve the quality of education at POLINDRA.

This research aims to first build Service Oriented Architecture (SOA) so as to get integrated data from Information System Akademik (SIAKAD), especially in the process of data collection. Second, analyzing the performance of lecturers using FAHP at the Indramayu State Polytechnic. Third, graph the results of lecturers' performance for real-time monitoring. The fourth is to make a decision support system for the best lecturer selection based on realtime.

\section{Materials and Methods}

\subsection{Materials}

The materials used to conduct research are (1) Academic Information System Database: used to build SOA web services by implementing the REST API that is able to respond to data requests that will be used for data analysis; (2) Questionnaire data: obtained from a lecturer performance questionnaire from students created at the end of the semester exam in the POLINDRA academic information system. Questionnaire with 17 questions including among them the quality of teaching and examinations; (3) Research and Service Data : obtained from the SIAKAD database and POLINDRA Research and Service Center (P3M). If the data in SIAKAD is incomplete, then an administrator will provide a form to input data manually; (4) Academic Regulations POLINDRA: obtained from a reference materials applicable system on case studies that will be examined, so that the information system is built not violate regulations. The criteria data used are as follows:

Table 1. Research Criteria

\begin{tabular}{lll}
\hline No & Code & \multicolumn{1}{c}{ Criteria } \\
\hline 1. & C1 & Performace \\
2. & C2 & Research Criteria \\
3. & C 3 & Criteria for community service \\
4. & C4 & Criteria for publication
\end{tabular}


Based on the material used, an information system is needed to conduct real-time data analysis. The design of the information system is built as follows. The design of the information system that is built can be seen in Fig.1.

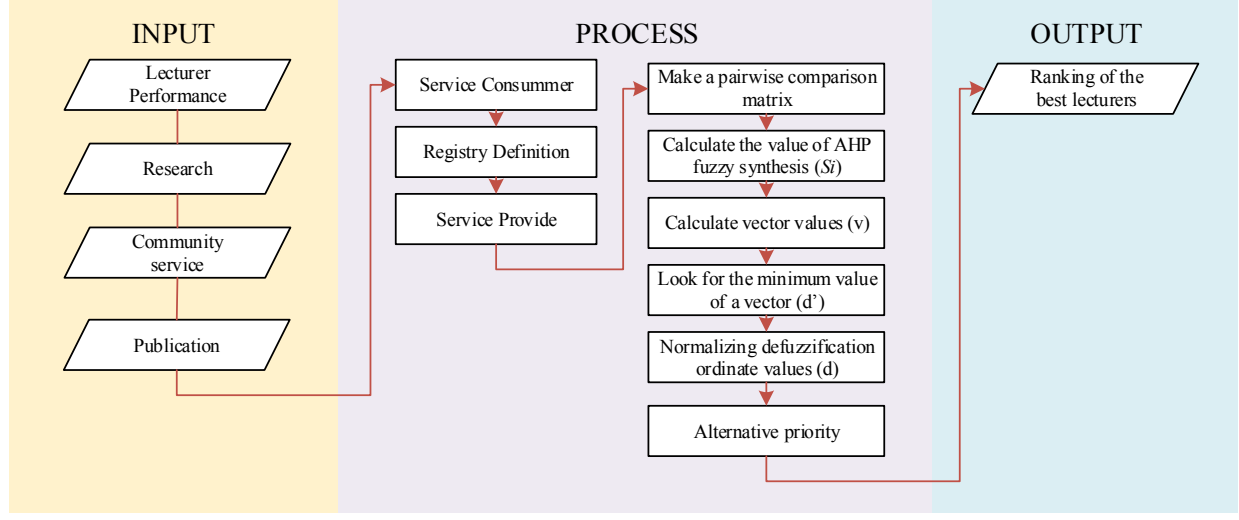

Fig. 1. Information System Framework

\subsection{Methods}

Service Oriented Architecture (SOA), a software development architecture technology with a service approach, allows the relationship and exchange of data or information between parts to be easy. Its loosely coupled (low level of interdependence of components), highly interoperable, reusable and interoperability make SOA reliable in developing and integrating information [16].

Fuzzy Analytic Hierarchy Process (FAHP) is a combination of AHP method with fuzzy logic. FAHP covered the weaknesses in the bias caused by its subjectivity and its imprecise nature of decision making, but the fuzzy set theory introduced by Zadeh in 1965 could enhance this analysis [17]. Fuzzy logic helps label and illustrate the deficiencies of traditional theories. It also uses binary logic which makes it possible to define various phenomena that cannot be revealed through other analyzes. The membership function model of fuzzy logic helps to analyze uncertainty and obscurity in a way that is comparable to human language.

Determination of the degree of FAHP membership uses the triangular fuzzy number (TFN) function. The membership function of a triangle is a combination of two lines (linear). The triangle graph is depicted on the shape of a triangular curve that can be seen in Fig. 2 [18].

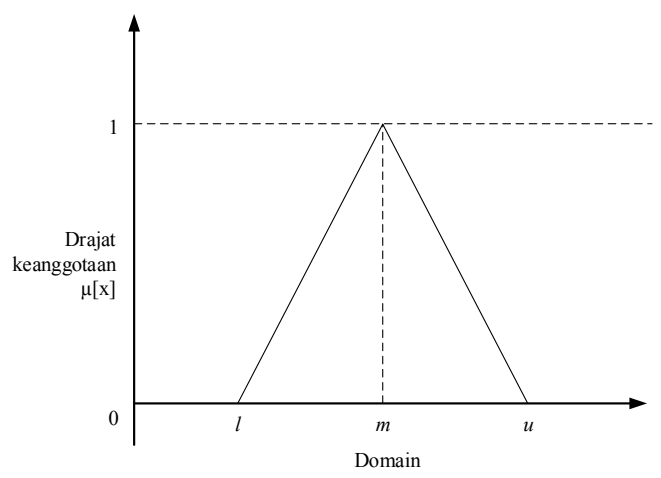

Fig. 2. The triangular membership function 
AHP intensity values are represented on a triangle fuzzy scale, which is to divide each fuzzy set by two (2), except for the intensity of importance one (1). The fuzzy scale used can be seen in table 3 .

Table 2. Scale of triangular fuzzy values

\begin{tabular}{|c|c|c|c|}
\hline $\begin{array}{l}\text { Intensity of } \\
\text { AHP } \\
\text { importance } \\
\end{array}$ & Linguistic Association & $\begin{array}{c}\text { Triangular } \\
\text { Fuzzy Number } \\
\text { (TFN) }\end{array}$ & Reciprocal \\
\hline 1 & $\begin{array}{l}\text { Just Equal : comparison of the } \\
\text { same elements }\end{array}$ & $(1,1,1)$ & $(1,1,1)$ \\
\hline 2 & Intermediate : Middle & $(1 / 2,1,3 / 2)$ & $(2 / 3,1,2)$ \\
\hline 3 & $\begin{array}{l}\text { Moderately important : one } \\
\text { element is quite important with } \\
\text { another }\end{array}$ & $(1,3 / 2,2)$ & $(1 / 2,2 / 3,1)$ \\
\hline 4 & $\begin{array}{l}\text { The intermediate ( element) of one } \\
\text { element is quite important from } \\
\text { another }\end{array}$ & $(3 / 2,2,5 / 2)$ & $(2 / 5,1 / 2,2 / 3)$ \\
\hline 5 & $\begin{array}{l}\text { Strongly important : one strong } \\
\text { element is important with another }\end{array}$ & $(2,5 / 2,3)$ & $(1 / 3,2 / 5,1 / 2)$ \\
\hline 6 & Intermediate : Middle & $(5 / 2,3,7 / 2)$ & $(2 / 7,1 / 3,2 / 5)$ \\
\hline 7 & $\begin{array}{l}\text { Very strong: one stronger element } \\
\text { is important with another }\end{array}$ & $(3,7 / 2,4)$ & $(1 / 4,2 / 7,1 / 3)$ \\
\hline 8 & Intermediate : Middle & $(7 / 2,4,9 / 2)$ & $(2 / 9,1 / 4,2 / 7)$ \\
\hline 9 & $\begin{array}{l}\text { Extremely strong : one element is } \\
\text { absolutely more important with } \\
\text { another }\end{array}$ & $(4,9 / 2,9 / 2)$ & $(2 / 9,2 / 9,1 / 4)$ \\
\hline
\end{tabular}

The TFN criteria on the linguistic scale can be defined on $t$ able 3 . starting from lowest to highest.

From the fuzzy membership function and the scale of values that have been defined, the steps for completing the FAHP are as follows [13].

- Create a hierarchical structure of the problem to be solved and determine pairwise comparisons between criteria with the TFN table (table 3).

- Determine the value of fuzzy synthesis $(\mathrm{Si})$ priority with equation 1

$$
S_{i}=\sum_{j=1}^{m} M_{g_{i}}^{j} \times \frac{1}{\left[\sum_{i=1}^{n} \sum_{j=1}^{m} M_{i}^{j}\right]}
$$

where $S i$ indicates the value of fuzzy synthesis, $\sum_{j=1}^{m} M_{g_{i}}^{j}$ namely summing cell values in the column starting from column 1 in each row of the matrix, $M$ represents the number TFN, $m$ is the number of criteria, $i$ is the row , and $j$ is the column matrix.

- After comparing the fuzzy synthesis values, the defuzzification ordinate value $\left(d^{\prime}\right)$ will be obtained with the minimum $d^{\prime}$ value. From the calculation table through equation 1 , the values $v$ and $d^{\prime}$ can be calculated. to calculate $V^{\prime}$ we use equation 2 .

$$
V\left(M_{2} \geq M_{1}\right)=\left\{\begin{array}{lc}
1, & \text { if } m_{2} \geq m_{1}, \\
0, & \text { if } l_{1} \geq u_{2}, \\
\frac{l_{1}-u_{2}}{\left(m_{2}-u_{2}\right)\left(m_{1}-l_{1}\right)}, & \text { selain diatas }
\end{array}\right.
$$

In the following vector search calculation, by comparing the value of synthesis $m$ on criterion 1 ( $\mathrm{SiK} 1)$ and synthesis value $\mathrm{m}$ on criterion 2 (SiK2). If the synthesis value of 
$m$ in criterion 1 is greater than the value of synthesis $m$ in criterion 2 , the vector value obtained is 1 .

- After getting the vector value, then define the ord inat d 'value using equation 3 .

$$
d^{\prime}\left(V K_{1}\right)=\min \left(V K_{1} \geq V K_{2}, \ldots, V K_{1} \geq V K_{n}\right)
$$

where the ordinate value of the criterion vector 1 is symbolized by $d^{\prime}\left(V K_{1}\right)$, then $V K_{1}$ is the criterion vector 1 and is the to- $n$ criterion vector.

- To calculate the weight value of fuzzy vectors $\left(W^{\prime}\right)$, calculate the value of fuzzy weights using the following equation.

$$
d^{\prime}\left(A_{i}\right)=\min V\left(S_{i} \geq S_{k}\right)
$$

where symbols $A_{i}$ are alternative criteria one until finished, then $S_{i}$ is the value of synthesis and $S_{k}$ is n use values synthesis of criteria

- Calculate the normalization of the weight value of fuzzy vectors $(W)$. This weight normalization will be done so that the values in the vector are allowed to be analog weights and consist of non-fuzzy numbers. Normalization is done using the following equation.

$$
W^{\prime}=\left(d^{\prime}\left(A_{1}\right), d^{\prime}\left(A_{2}\right), \ldots \ldots, d^{\prime}\left(A_{n}\right)\right) \quad \mathrm{T}
$$

where each element of vector weight is divided by the total weight of the vector itself and the total weight that has been normalized will be 1 . The normalization value of the fuzzy vector weight criteria is equal to the value of the global priority weight (which is the goal). After successfully weighting the criteria using Fuzzy AHP, the next step is to calculate alternative values using the Simple Additive Weighting (SAW) method. Simple Additive Weighting which is also known as a measurable linear combination or valuation method [8]. Simple Additive Weighting (SAW) is also a multi-attribute procedure based on the weighted sum concept. Look for a weighted sum of the performance evaluations of each alternative on all alternative criteria where the highest overall score is the best alternative and will be taken [9].

The procedure for completing the SAW method is through several stages of the process as follows [10]:

- Specify an alternative name Ai

- Determine the criteria to be used as a reference in decision making, i.e. Cj. Then identified the types of criteria, whether the criteria of excellence (benefit criteria) or cost criteria (cost criteria). If $\mathrm{Cj}$ is the benefit of the criteria the greater the value, the better the criteria for determining alternatives. If $\mathrm{Cj}$ is a cost attribute the smaller the value, the better the criteria for determining alternatives.

- Give a rating that matches the value of each alternative on each criterion.

- Determine the weight of preference or level of importance (W) of each criterion. In this study the weight of preference using the Fuzzy AHP method.

- Make a ranking table for the suitability of each alternative for each criterion.

- Make a decision matrix (X), which is formed from the table to rank the suitability of each alternative on each criterion. The value $(\mathrm{X})$ of each alternative $(\mathrm{Ai})$ on each predetermined criterion $(\mathrm{Cj})$, where in, $\mathrm{i}=1,2, \ldots \mathrm{m}$ and $\mathrm{j}=1,2, \ldots \mathrm{n}$.

$$
X=\left[\begin{array}{cccc}
X_{11} & X_{12} & \cdots & X_{1 j} \\
& \vdots & & \vdots \\
X_{i 1} & X_{i 2} & \cdots & X_{i j}
\end{array}\right]
$$

- Normalization of the decision matrix by calculating the performance rating normalized values (rij) of alternative $\mathrm{Ai}$ on the $\mathrm{Cj}$ criterion. 


$$
R=\left[\begin{array}{cccc}
r_{11} & r_{12} & \cdots & r_{1 j} \\
& \vdots & & \vdots \\
r_{i 1} & r_{i 2} & \cdots & r_{i j}
\end{array}\right]
$$

- The results of the normalized performance rating values rj form a normalized matrix (R).

$$
r_{i j}= \begin{cases}\frac{X_{i j}}{\operatorname{Max}_{i}\left(X_{i j}\right)} & \text { If } j \text { is benefit } \\ \frac{\operatorname{Min}_{i}\left(X_{i j}\right)}{X_{i j}} & \text { If } j \text { is cost }\end{cases}
$$

- The final result preference value (Vi) obtained from the number of rows of the normalized multiplication element matrix $(\mathrm{R})$ weighs the preference $(\mathrm{W})$ corresponding to the column element matrix $(\mathrm{W})$.

$$
V_{i}=\sum_{j=1}^{n} W_{j} r_{i j}
$$

The greater the preference value Vi obtained by the alternative, the better and stated first rank. If the smallest $\mathrm{Vi}$ value is considered not good and get the last rank.

\section{Implementation}

Building Service Oriented Architecture (SOA) with the aim to get integrated data from SIAKAD, especially in the process of data retrieval. The physical server installs an open source virtual machine application to support campus activities. SOA data that can be handled are majors, study programs, lecturers, lecturer performance. The network architecture that has been implemented in POLINDRA in Fig. 3.

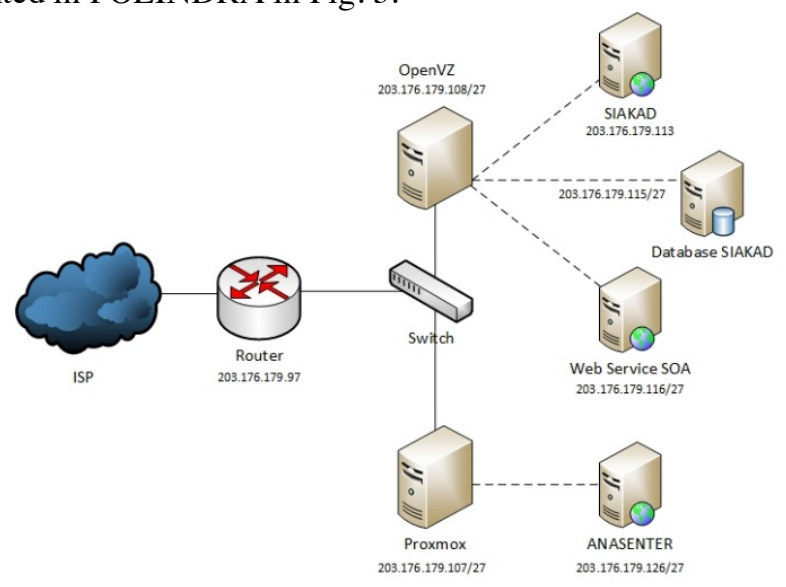

Fig. 3. Network Architecture

There are 2 virtual machine servers, using OpenVZ and Proxmox. Web service developed for SOA is installed on the OpenVZ machine with IP 203.176.179.116/27. The purpose of the web service being made a mechine with SIAKAD is to be able to handle data requests quickly. The SOA web service output generates the JSON format and uses the key as information system security.

Access POLINDRA SOA through the URL https://soa.polindra.ac.id/ by having Public IP 203,176,179,113 and port 443 (https). The SOA information system is implemented on a dedicated server with the Ubuntu server operating system LTS 14.04 and to facilitate the creation of virtual machines using OpenVZ software. 


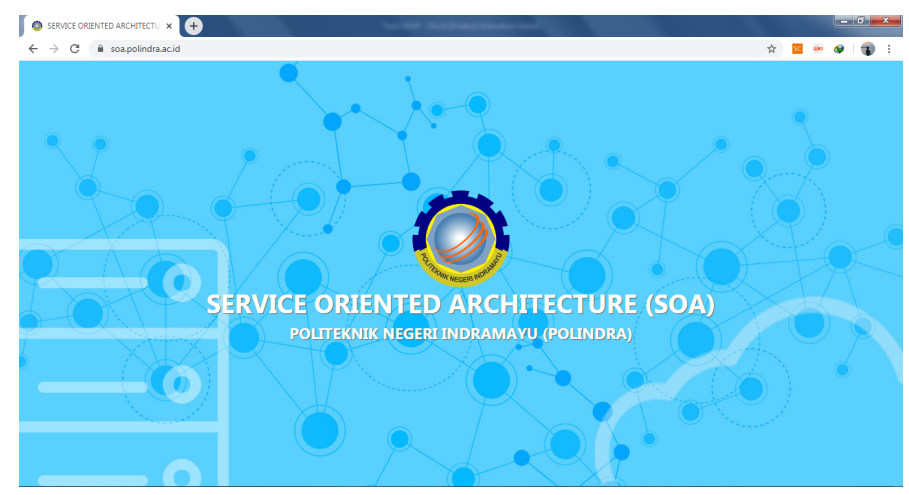

Fig. 4. Interface SOA Pages

The web server that is applied to analyze the performance of lecturers is given the name ANASENTER. The web server implementation is carried out on mechine proxmox with IP 203.176.179.126/27 and ubuntu server operating system LTS 16.04. Considering the information system security level, the protocol uses port 443 or https. The URL address used to access is https://anasenter.polindra.ac.id as in Fig. 5.

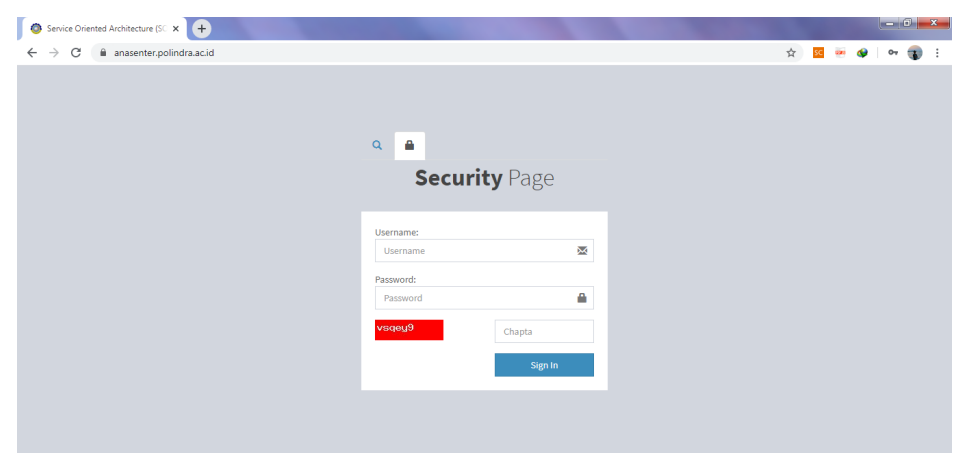

Fig. 5. Interface ANASENTER Page

The first step of the fuzzy AHP-SAW method is to determine the interests of each criterion by using a pairwise comparison matrix. Paired comparison matrices are made by executives or stakeholders in POLINDRA. The way to read the matrix is to determine the importance of the criteria row by the criteria column, if the criteria row is more important to the criteria column then it has a TFN value and if the criteria row is less important to the criteria column then the Receprocal value is given on the rulechang page. Determination of the intensity of importance is very influential on the output of the resulting criteria weights. The matrix page display is as follows. 


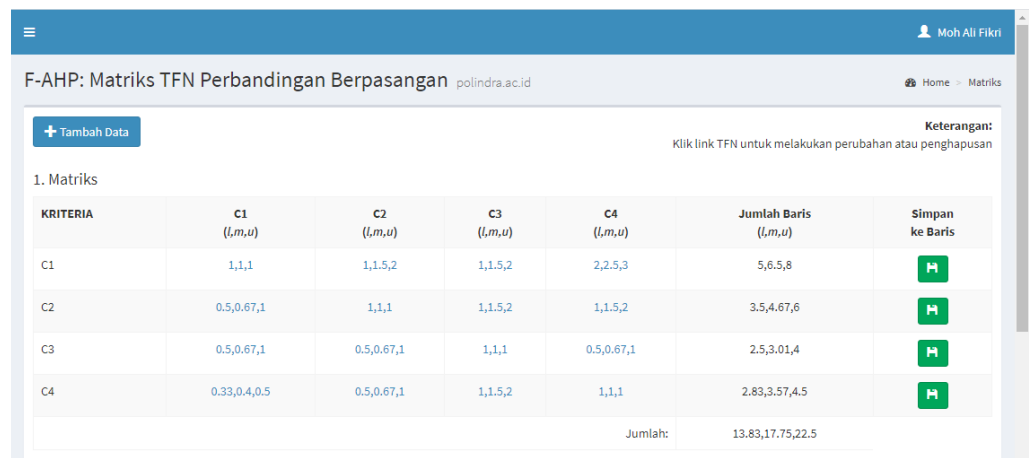

Fig. 6. Interface the FAHP matrix page

The matrix is calculated the number of TFN values $(1, \mathrm{~m}, \mathrm{u})$ to process the calculation of the synthesis value. The number of criteria rows generated from the matrix is in table 3 .

Table 3. Pairwise comparison matrix row values

\begin{tabular}{cccc}
\hline Criteria & $l$ & $m$ & $u$ \\
\hline C1 & 5 & 6.5 & 8 \\
C2 & 3.5 & 4.67 & 6 \\
C3 & 2.5 & 3.01 & 4 \\
C4 & 2.83 & 3.57 & 4.5 \\
Amount: & 13.83 & 17.75 & 22.5 \\
\hline
\end{tabular}

Then each value $(l, m, u)$ of each criterion is calculated to obtain the value of synthesis by equation 1 . The following calculations to find the value of synthesis $(\mathrm{Si})$ :

- Performance Criteria (C1)

$$
\text { Si }=(5,6.5,8) \times\left(\frac{1}{22.5}, \frac{1}{17.75}, \frac{1}{13.83}\right)=0.22,0.37,0.58
$$

- Research Criteria (C2)

$$
\text { Si }=(3.5,4.67,6) \times\left(\frac{1}{22.5}, \frac{1}{17.75}, \frac{1}{13.83}\right)=0.16,0.26,0.43
$$

- Criteria for community service (C3)

$$
\text { Si }=(2.5,3.01,4) \times\left(\frac{1}{22.5}, \frac{1}{17.75}, \frac{1}{13.83}\right)=0.11,0.17,0.29
$$

- Criteria for publication $(\mathrm{C} 4)$

$$
\mathrm{Si}=(2.83,3.57,4.5) \times\left(\frac{1}{22.5}, \frac{1}{17.75}, \frac{1}{13.83}\right)=0.13,0.2,0.33
$$
below.

So the synthesis value obtained from the calculation of equation 1 can be seen in table 5

Table 4. AHP fuzzy synthesis values

\begin{tabular}{cccc}
\hline Criteria & $l$ & $m$ & $u$ \\
\hline C1 & 0.22 & 0.37 & 0.58 \\
C2 & 0.16 & 0.26 & 0.43 \\
C3 & 0.11 & 0.17 & 0.29 \\
C4 & 0.13 & 0.2 & 0.33 \\
\hline
\end{tabular}

The next step is to find the defuzzification ordinate value $\left(d^{\prime}\right)$ with equation 2 by comparing the starting value of synthesis $m$ in criterion 1 with the synthesis value $m$ in other criteria. The process of calculating equation 2 is as follows:

- Lecturer Performance Criteria (C1) with other criteria.

$\mathrm{C} 1 \geq \mathrm{C} 1 \quad=1$ 
$\mathrm{C} 1 \geq \mathrm{C} 2 \quad=1$

$\mathrm{C} 1 \geq \mathrm{C} 3 \quad=1$

$\mathrm{C} 1 \geq \mathrm{C} 4=1$

Next define the ordinate value $d^{\prime}$ using equation 3 as follows:

$\begin{aligned} d^{\prime}(C 1) & =\min (1,1,1,1) \\ & =1\end{aligned}$

- Research Criteria (C2) with other criteria.

$\mathrm{C} 2 \geq \mathrm{C} 1=\frac{l_{1}-u_{2}}{\left(m_{2}-u_{2}\right)-\left(m_{1}-l_{1}\right)}=\frac{0,22-0,58}{(0,26-0,43)-(0,37-0,22)}=0.66$

$\mathrm{C} 2 \geq \mathrm{C} 2=1$

$\mathrm{C} 2 \geq \mathrm{C} 3=1$

$\mathrm{C} 2 \geq \mathrm{C} 4=1$

Next define the ordinate value $d^{\prime}$ using equation 3 as follows:

$d^{\prime}(C 2)=\min (0.66,1,1,1)$

$=0.66$

- Criteria for Community Service (C3) with other criteria.

$\begin{array}{ll}\mathrm{C} 3 \geq \mathrm{C} 1 & =\frac{l_{1}-u_{3}}{\left(m_{3}-u_{3}\right)-\left(m_{1}-l_{1}\right)}=\frac{0.22-0.29}{(0.17-0.29)-(0.37-0.22)}=0.26 \\ \mathrm{C} 3 \geq \mathrm{C} 2 & =\frac{l_{2}-u_{3}}{\left(m_{3}-u_{3}\right)-\left(m_{2}-l_{2}\right)}=\frac{0.16-0.29}{(0.17-0.29)-(0.16-0.26)}=0.59 \\ \mathrm{C} 3 \geq \mathrm{C} 3 & =1 \\ \mathrm{C} 3 \geq \mathrm{C} 4 & =\frac{l_{4}-u_{3}}{\left(m_{3}-u_{3}\right)-\left(m_{4}-l_{4}\right)}=\frac{0.13-0.29}{(0.17-0.29)-(0.2-0.13)}=0.84\end{array}$

Next define the ordinate value $d^{\prime}$ using equation 3 as follows:

$d^{\prime}(C 3)=\min (0.26,0.59,1,0.84)$

$=0.26$

- Publication Criteria (C4) with other criteria.

$\mathrm{C} 4 \geq \mathrm{C} 1=\frac{l_{1}-u_{4}}{\left(m_{4}-u_{4}\right)-\left(m_{1}-l_{1}\right)}=\frac{0.22-0.33}{(0.2-0.33)-(0.37-0.22)}=0.39$

$\mathrm{C} 4 \geq \mathrm{C} 2=\frac{l_{2}-u_{4}}{\left(m_{4}-u_{4}\right)-\left(m_{2}-l_{2}\right)}=\frac{0.16-0.33}{(0.2-0.33)-(0.26-0.16)}=0.74$

$\mathrm{C} 4 \geq \mathrm{C} 3=1$

$\mathrm{C} 4 \geq \mathrm{C} 4=1$

Next define the ordinate value $d^{\prime}$ using equation 3 as follows:

$d^{\prime}(C 4)=\min (0.39,0.74,1,1)$ $=0.39$

The results of the ordinate calculation can be seen in detail in table 6 to facilitate the next AHP fuzzy step process.

Table 5. AHP fuzzy ordinate vector values

\begin{tabular}{lccccc}
\hline Criteria & C1 & C2 & C3 & C4 & $d^{\prime}$ \\
\hline C1 & 1 & 1 & 1 & 1 & 1 \\
C2 & 0.66 & 1 & 1 & 1 & 0.66 \\
C3 & 0.26 & 0.59 & 1 & 0.84 & 0.26 \\
C4 & 0.39 & 0.74 & 1 & 1 & 0.39 \\
\hline
\end{tabular}

The next step is the normalization of the weight of the fuzzy vector $(W)$ using equation 5 . The results of the normalization can be seen in the following table. 
Table 6. Normalization results of fuzzy vector weights $(W)$

\begin{tabular}{cc}
\hline Criteria & $W$ \\
\hline $\mathrm{C} 1$ & 0.43 \\
$\mathrm{C} 2$ & 0.29 \\
$\mathrm{C} 3$ & 0.11 \\
$\mathrm{C} 4$ & 0.17 \\
Amount & 1 \\
\hline
\end{tabular}

From the results of table 7 get the value of performance shows $(\mathrm{C} 1)=0.43$, research $(\mathrm{C} 2)$ $=0.29$, devotion $(\mathrm{C} 3)=0.11$ and publication $(\mathrm{C} 4)=0.17$ so that if added together get a value of 1 . Furthermore the value obtained will be used as a weighting criterion to get the best lecturer ranking at POLINDRA.

The purpose of this research is to find the best lecturer ranking at POLINDRA. Ranking or ranking based on the level of department and college. Ranking is obtained from the calculation of AHP fuzzy weights with lecturer performance data for one year.

The lecturer criterion data is calculated to obtain an alternative matrix with equation 6 , which is represented in the table as in Figure 7.

\begin{tabular}{|c|c|c|c|c|c|c|}
\hline KODE DOSEN & NAMA & c1 & C2 & C3 & C4 & JUMLAH \\
\hline 2017070015 & A SUMARUDIN,,S.Pd., M.T & 3.1684399999999995 & 2 & 1 & 13 & 19.16844 \\
\hline 2017070009 & TITO ENDRAMAWAN,,S.Pd.,M.En & 3.408525 & 2 & 2 & 8 & 15.408525 \\
\hline 2017070035 & FELIX DIONISIUS,ST,MT & 3.310133333333333 & 3 & 2 & 7 & 15.310133333333 \\
\hline 2017090003 & ADI SUHERYADI,S.ST.,M.Ko & 3.0174333333333334 & 2 & 1 & 9 & 15.017433333333 \\
\hline 2018080001 & Alifia Puspaningrum,S.Pd.,M.Ko & 3.3796749999999998 & 2 & 1 & 8 & 14.379675 \\
\hline 2017070031 & AGUS SIFA,S.Pd., M.T & 3.0563000000000002 & 2 & 2 & 7 & 14.0563 \\
\hline 2017070002 & BADRUZZAMAN,S.ST.,MT & 3.6793333333333336 & 1 & 2 & 7 & 13.679333333333 \\
\hline 2017090005 & Meri Rahmi & 3. 313133333333333 & 3 & 1 & 6 & 13.313133333333 \\
\hline 2017070028 & WILLY PERMANA PUTRA,S.T., M.En & 3.2159 & 2 & 1 & 7 & 13.2159 \\
\hline 2017070083 & SULIONO,S.T., M.T & 2.7871 & 3 & 2 & 5 & 12.7871 \\
\hline 2017070034 & DELFFIKA CANRA,S.T.,M.T & 3.4736400000000005 & 3 & 1 & 4 & 11.47364 \\
\hline 2017070005 & DEDI SUWANDI,S.ST., M.T & 3.3259333333333334 & 2 & 1 & 5 & 11.325933333333 \\
\hline 2017070006 & EMIN HARIS,ST.,M.Eng & 3.40915 & 2 & 1 & 4 & 10.40915 \\
\hline 2017070016 & AHMAD LUBIS GHOZALI,-S. Kom.,M & 3.23532 & 2 & 1 & 4 & 10.23532 \\
\hline 2017070078 & IRYANTO,S.Si., M.S & 3.1936142857142857 & 2 & 1 & 4 & 10.193614285714 \\
\hline
\end{tabular}

Fig. 7. Alternative SAW decision matrix

The lecturer data with 66 records in the SAW decision matrix is then searched for minimum and maximum values for each criterion to normalize the data.

Table 7. Max and min values of the SAW decision matrix table

\begin{tabular}{lcc}
\hline Criteria & Max & Min \\
\hline C1 & 3.8128 & 0 \\
C2 & 3 & 0 \\
C3 & 2 & 0 \\
C4 & 13 & 0 \\
\hline
\end{tabular}


By knowing the maximum and minimum values, the type of $\mathrm{Cj}$ criteria can be determined, whether the benefits or costs. In this study all types of criteria use the benefit equation that is the greater the value the better. Continue the data normalization process using equation 7 with the following results.

\begin{tabular}{|c|c|c|c|c|c|c|}
\hline KODE DOSEN & NAMA & c1 & C2 & c3 & C4 & JUMLAH \\
\hline 2017070035 & FELIX DIONISIUS,ST,MT & 0.86816337949364 & 1 & 1 & 0.53846153846154 & 3.4066249179552 \\
\hline 2017070009 & TITO ENDRAMAWAN,,S.Pd.,M.En & 0.89396899916072 & 0.66666666666667 & 1 & 0.61538461538462 & 3.176020281212 \\
\hline 2017070083 & SULIONO,S.T., M.T & 0.73098510281158 & 1 & 1 & 0.38461538461538 & 3.115600487427 \\
\hline 2017070031 & AGUS SIFA,S.Pd., M.T & 0.80158938313051 & 0.666666666666667 & 1 & 0.53846153846154 & 3.0067175882587 \\
\hline 2017070015 & A SUMARUDIN,,S.Pd., M.T & 0.83100083927822 & 0.666666666666667 & 0.5 & 1 & 2.9976675059449 \\
\hline 2017070002 & BADRUZZAMAN,S.ST.,MT & 0.96499510421038 & 0.33333333333333 & 1 & 0.53846153846154 & 2.8367899760053 \\
\hline 2017090005 & Meri Rahmi & 0.86895020282557 & 1 & 0.5 & 0.46153846153846 & 2.830488664364 \\
\hline 2017070034 & DELFFIKA CANRA,S.T.,M.T & 0.91104699958036 & 1 & 0.5 & 0.30769230769231 & 2.7187393072727 \\
\hline 2018080001 & Alifia Puspaningrum,S.Pd.,M.Ko & 0.88640238145195 & 0.66666666666667 & 0.5 & 0.61538461538462 & 2.6684536635032 \\
\hline 2017090003 & ADI SUHERYADI,S.ST.,M.Ko & 0.79139564974122 & 0.666666666666667 & 0.5 & 0.69230769230769 & 2.6503700087156 \\
\hline 2017070085 & YUSUP NUR ROHMAT,S.T.,M.T & 0.79039682123374 & 0.666666666666667 & 1 & 0.15384615384615 & 2.6109096417466 \\
\hline 2017070028 & WILLY PERMANA PUTRA,S.T., M.En & 0.84344838438943 & 0.66666666666667 & 0.5 & 0.53846153846154 & 2.5485765895176 \\
\hline 2017070030 & YUDHY KURNIAWAN,S.T.,M.T & 0.89217897608057 & 1 & 0.5 & 0.15384615384615 & 2.5460251299267 \\
\hline 2017070005 & DEDI SUWANDI,S.ST., M.T & 0.87230731570849 & 0.666666666666667 & 0.5 & 0.38461538461538 & 2.4235893669905 \\
\hline 2017070006 & EMIN HARIS,ST.,M.Eng & 0.89413292068821 & 0.66666666666667 & 0.5 & 0.30769230769231 & 2.3684918950472 \\
\hline
\end{tabular}

Fig. 8. Alternative SAW decision matrix

From the results obtained by normalizing the matrix table in Figure 8, ranking or ranking for the SAW method can be determined. The following information results from ranking calculations using the SAW method.

\begin{tabular}{|c|c|c|c|c|c|c|c|}
\hline $\begin{array}{l}\text { KODE } \\
\text { DOSEN }\end{array}$ & NAMA & C1 & C2 & C3 & $\mathrm{C} 4$ & JUMLAH & RANK \\
\hline 2017070035 & FELIX DIONISIUS,ST,MT & 0.86816337949364 & 1 & 1 & 0.53846153846154 & 3.4066249179552 & 1 \\
\hline 2017070009 & TITO ENDRAMAWAN,,S.Pd.,M.En & 0.89396899916072 & 0.66666666666667 & 1 & 0.61538461538462 & 3.176020281212 & 2 \\
\hline 2017070083 & SULIONO,S.T., M.T & 0.73098510281158 & 1 & 1 & 0.38461538461538 & 3.115600487427 & 3 \\
\hline 2017070031 & AGUS SIFA,S.Pd., M.T & 0.80158938313051 & 0.66666666666667 & 1 & 0.53846153846154 & 3.0067175882587 & 4 \\
\hline 2017070015 & A SUMARUDIN,,S.Pd., M.T & 0.83100083927822 & 0.66666666666667 & 0.5 & 1 & 2.9976675059449 & 5 \\
\hline 2017070002 & BADRUZZAMAN,S.ST.,MT & 0.96499510421038 & 0.33333333333333 & 1 & 0.53846153846154 & 2.8367899760053 & 6 \\
\hline 2017090005 & Meri Rahmi & 0.86895020282557 & 1 & 0.5 & 0.46153846153846 & 2.830488664364 & 7 \\
\hline 2017070034 & DELFFIKA CANRA,S.T.,M.T & 0.91104699958036 & 1 & 0.5 & 0.30769230769231 & 2.7187393072727 & 8 \\
\hline 2018080001 & Alifia Puspaningrum,S.Pd.,M.Ko & 0.88640238145195 & 0.66666666666667 & 0.5 & 0.61538461538462 & 2.6684536635032 & 9 \\
\hline 2017090003 & ADI SUHERYADI,S.ST.,M.Ko & 0.79139564974122 & 0.66666666666667 & 0.5 & 0.69230769230769 & 2.6503700087156 & 10 \\
\hline 2017070085 & YUSUP NUR ROHMAT,S.T.,M.T & 0.79039682123374 & 0.666666666666667 & 1 & 0.15384615384615 & 2.6109096417466 & 11 \\
\hline 2017070028 & WILLY PERMANA PUTRA,S.T., M.En & 0.84344838438943 & 0.66666666666667 & 0.5 & 0.53846153846154 & 2.5485765895176 & 12 \\
\hline 2017070030 & YUDHY KURNIAWAN,S.T.,M.T & 0.89217897608057 & 1 & 0.5 & 0.15384615384615 & 2.5460251299267 & 13 \\
\hline 2017070005 & DEDI SUWANDI,S.ST., M.T & 0.87230731570849 & 0.666666666666667 & 0.5 & 0.38461538461538 & 2.4235893669905 & 14 \\
\hline 2017070006 & EMIN HARIS,ST.,M.Eng & 0.89413292068821 & 0.66666666666667 & 0.5 & 0.30769230769231 & 2.3684918950472 & 15 \\
\hline
\end{tabular}

Fig. 9. Ranking using the SAW method

The ranking obtained from the SAW method received the highest score of 3.40 with lecturer Felix Dionisius, ST, MT. The results of the SAW method in Figure 9 are then combined with the criteria weights that have been obtained from the Fuzzy AHP method. 


\begin{tabular}{|c|c|c|c|c|c|c|c|c|}
\hline KODE & $\begin{array}{l}\text { KODE } \\
\text { DOSEN }\end{array}$ & NAMA & c1 & c2 & c3 & C4 & NILAI & RANGKING \\
\hline \multicolumn{3}{|c|}{ Bobot Kriteria } & 0.43290043290043 & 0.28571428571429 & 0.11255411255411 & 0.16883116883117 & & \\
\hline A027 & 2017070035 & FELIX DIONISIUS,ST,MT & 0.3758283028111 & 0.28571428571429 & 0.11255411255411 & 0.090909090909092 & 0.86500579198859 & 1 \\
\hline A041 & 2017090005 & Meri Rahmi & 0.37616891897211 & 0.28571428571429 & 0.056277056277055 & 0.077922077922078 & 0.79608233888553 & 2 \\
\hline A062 & 2017070009 & TITO ENDRAMAWAN,,S.Pd.M.En & 0.38699956673624 & 0.19047619047619 & 0.11255411255411 & 0.10389610389611 & 0.79392597366265 & 3 \\
\hline $\mathrm{A} 020$ & 2017070034 & DELFFIKA CANRA,S.T.M.T & 0.39439264051098 & 0.28571428571429 & 0.056277056277055 & 0.051948051948053 & 0.78833203445037 & 4 \\
\hline A059 & 2017070083 & SULIONO,S.T., M.T & 0.3164437674509 & 0.28571428571429 & 0.11255411255411 & 0.064935064935065 & 0.77964723065436 & 5 \\
\hline A001 & 2017070015 & A SUMARUDIN,,S.Pd., M.T & 0.35974062306416 & 0.19047619047619 & 0.056277056277055 & 0.16883116883117 & 0.77532503864858 & 6 \\
\hline A067 & 2017070030 & YUDHY KURNIAWAN,S.T.,M.T & 0.38622466496994 & 0.28571428571429 & 0.056277056277055 & 0.025974025974026 & 0.75419003293531 & 7 \\
\hline A005 & 2017070031 & AGUS SIFA,S.Pd., M.T & 0.34700839096559 & 0.19047619047619 & 0.11255411255411 & 0.090909090909092 & 0.74094778490498 & 8 \\
\hline A009 & 2018080001 & Alifia Puspaningrum,S.Pd.,M.Ko & 0.38372397465452 & 0.19047619047619 & 0.056277056277055 & 0.10389610389611 & 0.73437332530388 & 9 \\
\hline A014 & 2017070002 & BADRUZZAMAN,S.ST.,MT & 0.41774679835947 & 0.095238095238096 & 0.11255411255411 & 0.090909090909092 & 0.71644809706077 & 10 \\
\hline A004 & 2017090003 & ADI SUHERYADI,S.ST.,M.Ko & 0.34259551936849 & 0.19047619047619 & 0.056277056277055 & 0.11688311688312 & 0.70623188300486 & 11 \\
\hline A065 & 2017070028 & WILLY PERMANA PUTRA,S.T., M.En & 0.36512917073135 & 0.19047619047619 & 0.056277056277055 & 0.090909090909092 & 0.70279150839369 & 12 \\
\hline A019 & 2017070005 & DEDI SUWANDI,S.ST., M.T & 0.37762221459242 & 0.19047619047619 & 0.056277056277055 & 0.064935064935065 & 0.68931052628073 & 13 \\
\hline A015 & 2018010003 & BOBI KHOERUN,S.Pd.,MT & 0.40032617403578 & 0.19047619047619 & 0.056277056277055 & 0.038961038961039 & 0.68604045975007 & 14 \\
\hline
\end{tabular}

Fig. 10. Ranking of the best lecturers of the Fuzzy AHP-SAW method

The results show that the first rank value is 0.86 with alternative code A027 with the name Felix Dionisius, ST, MT from the Department of Mechanical Engineering. The second rank is 0.796 with an alternative code A041 with the name Meri Rahmi from the Department of Mechanical Engineering and the third rank is 0.793 with the name Tito Endramawan, S.Pd., M.Eng from the Department of Mechanical Engineering of the Polytechnic State of Indramayu.

\section{Result and Discussion}

The preference value graph from the calculation results of the Fuzzy AHP method becomes the determining factor for the best lecturer ranking at POLINDRA. There are 4 variables measured, namely performance $(\mathrm{C} 1)$, research $(\mathrm{C} 2)$, dedication $(\mathrm{C} 4)$, publication $(\mathrm{C} 4)$. Each of these variables has the weight of the criteria displayed on the graph with the aim of being easily understood by the lecturer. Criteria weights are calculated through a pairwise Fuzzy AHP comparison matrix by taking into account the importance level. The lecturer criterion data included in the database as a reference for Fuzzy AHP-SAW calculation can be seen and validated, so that the system built can be justified .

The lecturer ranking can be seen in detail on the lecturer page by including the national lecturer ID number (NIDN). The information presented starts from the college level ranking up to the department level. The goal is to be able to provide motivation to related lecturers to be able to improve their performance better. The lecturer page rank can be seen in Fig. 11. 


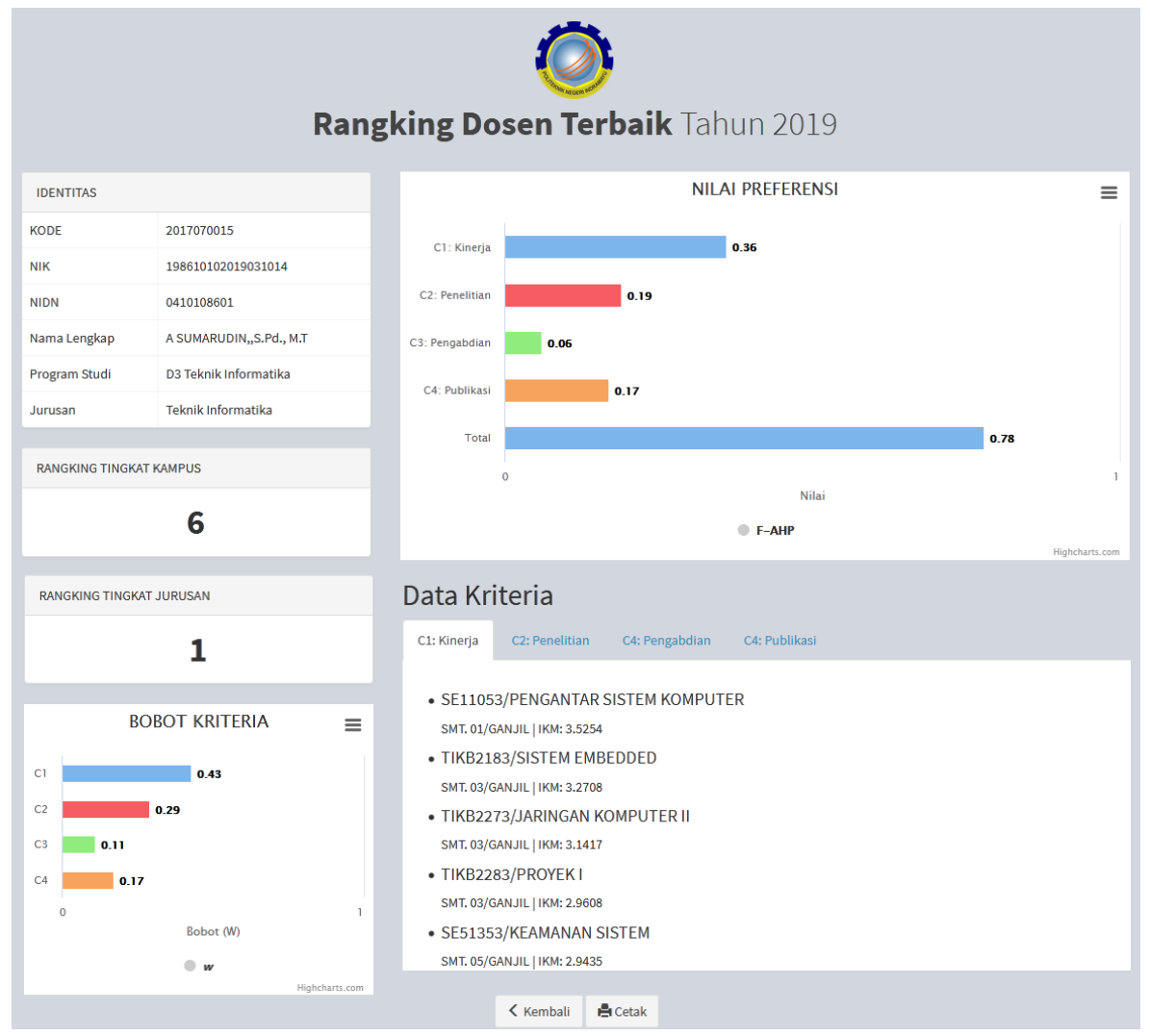

Fig. 11. Interface rankings of the best lecturers

Fig. 8 shows a lecturer by the name A. Sumarudin with NIDN 0410108601 from the informatics engineering department getting a preference value of 0.78 from each of the $\mathrm{C} 1$ criteria $0.36 \mathrm{C} 20.19 \mathrm{C} 30.06 \mathrm{C} 40.17$ so as to get a ranking of 1 (first) level of majors and ranking of 6 (six) campus levels. Lecturers can check the criteria data that is used as the fuzzy AHP-SAW calculation process, so that the best lecturer analysis information system is built with transparency.

Lack of research conducted occurs in the process of collecting research data, service and publication. The data produced by the interview at research center POLINDRA is in the form of an excel file recapitulation, so the research requires a careful process to normalize the data to be entered into the database.

\section{Conclusions}

Information system integration using SOA methods is able to communicate well. SOA data that can be handled are majors, study programs, lecturers, lecturer performance. The results of the message delivery service carried out by the web service with 150 performance table records , 69 lecturer records tables , 6 record study programs and 3 record majors have been successful.

AHP fuzzy analysis method to find the best lecturers has been successfully carried out by producing fuzzy vector weights (w) performance performance criteria $(\mathrm{C} 1) 0.43$, research (C2) 0.29 , dedication (C3) 0.11 and publication (C4) 0.17 with the number of lecturers (alternative) as many as 69. The results showed an alternative code A063 with a $\mathrm{C} 1$ value of 
$0.38 \mathrm{C} 20.22 \mathrm{C} 30.08 \mathrm{C} 40.15$. The results show that the first rank value is 0.86 with alternative code A027 with the name Felix Dionisius, ST, MT from the Department of Mechanical Engineering. The second rank is 0.796 with an alternative code A041 with the name Meri Rahmi from the Department of Mechanical Engineering and the third rank is 0.793 with the name Tito Endramawan, S.Pd., M.Eng from the Department of Mechanical Engineering of the Polytechnic State of Indramayu.

The preference value graph from the calculation results of the Fuzzy AHP method becomes the determining factor for the best lecturer ranking at POLINDRA. There are 4 variables measured, namely performance $(\mathrm{C} 1)$, research $(\mathrm{C} 2)$, dedication $(\mathrm{C} 4)$, publication (C4). Each of these variables has the weight of the criteria displayed on the graph with the aim of being easily understood by the lecturer.

\section{Acknowledgments}

The author would like to thank the PasTi scholarship program of the Indonesia Ministry of Research Technology and Higher Education.

\section{References}

1. P. Jiang, M. Elag, P. Kumar, S.D. Peckham, L. Marini, L. Rui, "A service-oriented architecture for coupling web service models using the Basic Model Interface (BMI)," Environmental Modelling \& Software 92, pp. 107-118, (2017).

2. A. Navarro and A.d. Silva, "A metamodel-based definition of a conversion mechanism between SOAP and RESTful web services," Computer Standards \& Interfaces, pp. 4970, (2016).

3. Ahmed and Kilic, "Fuzzy Analytic Hierarchy Process: A performance analysis of various algorithms," Fuzzy Sets and Systems Vol. 362, pp. 110-128, (2019).

4. S.-H. Tsaur, T.-Y. Chang, C.-H. Yen, "The evaluation of airline service quality by fuzzy MCDM," Tourism Management, pp. 107-115, (2002).

5. Owusu-Agyeman dkk., "An embedded fuzzy analytic hierarchy process for evaluating lecturers' conceptions of teaching and learning," Studies in Educational Evaluation 55, pp. 46-57, (2017).

6. N.Ç. Gören, E. Gören, D. Öznaz, C.D., “Textile program students' evaluation of lecturers," Procedia Social and Behavioral Sciences 2, p. 3442-3446, (2010).

7. A. Gnanavelbabu and P. Arunagiri, "Ranking of MUDA using AHP and Fuzzy AHP algorithm," Materials Today: Proceedings 5, p. 13406-13412, (2018).

8. A.R. Afshari, ,M. Nikolic, Z. Akbari, "PERSONNEL SELECTION USING GROUP FUZZY AHP AND SAW," JOURNAL OF ENGINEERING MANAGEMENT AND COMPETITIVENESS (JEMC), vol. 7, no. 1, pp. 3-10, (2017).

9. J. Malczewski, GIS and Multicriteria Decision Analysis, illustrated ed, 1999.

10. E.R. Setyani and R. Saputra, "Flood-prone Areas Mapping at Semarang City By Using Simple Additive Weighting Method," Procedia - Social and Behavioral Sciences 227, p. $378-386$, (2016).

11. O. Cizela da Costa Tavares, Suyoto, Pranowo, "Hybrid Method for Mobile learning Cooperative: Study of Timor Lest," E3S Web of Conferences 31, p. 10005, (2018). 
12. Y-J. Wang, "Combining quality function deployment with simple additive weighting for interval-valued fuzzy multi-criteria decision-making with dependent evaluation criteria," Soft Computing , vol. 24, p. 7757-7767, (2019).

13. H.V. Blottnitz, J.M. Case, D.M. Fraser, "Sustainable development at the core of undergraduate engineering curriculum reform: a new introductory course in chemical engineering," Journal of Cleaner Production, pp. 300-307, (2015).

14. F.E. Daromes and NG Suwandi, "Embedding core value into the internal quality assurance systems in higher education," Procedia - Social and Behavioral Sciences, p. 660-664, (2015).

15. S. Lindblom-Ylänne, K. Trigwell, A. Nevgi, P. Ashwin, "How approaches to teaching are effected by discipline and teaching context," Studies in Higher Education, p. 285298, (2006).

16. T. Erl, SOA Principles of Service Design, USA: Prentice Hall Press Upper Saddle River, (2016).

17. L.A. Zadeh, "Fuzzy sets," Information and Control, pp. 338-353, (1965).

18. Chang, "Applications of the extent analysis method on fuzzy AHP," European Journal of Operational Research 95, pp. 649-655, (1996).

19. T. L. Saaty, Fundamentals of decision making and priority theory with the analytic hierarchy process, Pittsburgh: RWS Publications, (1984).

20. T. L. Saaty, The analytic hierarchy process, planning, priority, setting, resource allocation, New York: Mc-Graw Hill, (1980.)

21. P. J. M. Van Laarhoven and W. Pedrycz, "Fuzzy extension for Saaty's priority theory," Fuzzy Sets and Systems, vol. 11, p. 229-241, (1983).

22. J. Buckley, "Fuzzy hierarchical analysis," Fuzzy Sets and Systems, vol. 17, p. 233-247, (1985).

23. C. H. Cheng, "Evaluating naval tactical missile systems by fuzzy AHP based on the grade value of membership function," European Journal of Operational Research, vol. 96, p. 343-350, (1996.)

24. L. Mikhailov, "Deriving priorities from fuzzy pairwise comparison judgements," Fuzzy Sets and Systems, vol. 134, no. 3, p. 365-385, (2003). 